\title{
MORE ON THE DEVELOPMENT OF PROFESSIONAL SELF-CONSCIOUSNESS OF FUTURE LAWYERS
}

\author{
Mikhail Smirnov $^{1 *}$, Larisa Monakhova ${ }^{2}$ \\ ${ }^{1}$ Assoc. Prof. Dr., Mari State University, Russia, micsha.smi2015@yandex.ru \\ ${ }^{2}$ Assoc. Prof. Dr., Mari State University, Russia laranka@mail.ru \\ ${ }^{*}$ Corresponding Author
}

\begin{abstract}
The issues of developing the professional self-consciousness of a lawyer are becoming particularly relevant due to the aggravation of contradictions between the existing level of practical training of future lawyers and the objective needs of improving higher legal education. In this regard, an important social and psychological task of the higher law school at the present stage of society development is the formation of a professionallyoriented self-consciousness of future lawyers as a prerequisite for their further successful activity. The problem of creating such conditions that would allow constant improvement of lawyers' self-consciousness is of great importance. Practice shows that only those specialists who are able to include these changes in the context of the cognitive, emotional and behavioral components of their personality, having meaningfully and instrumentally mastered them at the level of understanding, attitude and activity, can adapt to diverse, cardinal changes in the conditions of professional activity.
\end{abstract}

The efficiency of the professional activity of future lawyers is determined by the peculiarities of their professional self-consciousness, which cannot be developed without purposeful work on the formation of knowledge and skills necessary for young professionals in the conditions of changing reality, on the development of professionally significant qualities that enable young specialists not only to adapt to the conditions of professional activity, but also to engage in it with the greatest benefit for their personal development and professional success.

The choice of the topic for this study was based on the need to determine the features of the manifestation of personal self-consciousness in the activity and to develop diagnostic tools for their assessment, search and determination of the conditions and factors for the development of general characteristics of professional self-consciousness of future lawyers that determine the efficiency of their activity.

Keywords: Professional self-consciousness, psychological structure of the individual, professional adaptation, psychological skills and abilities, university training, interactive teaching methods, professional activity.

\section{INTRODUCTION}

The importance of the problem of developing professional self-consciousness of future lawyers in the conditions of university training is determined by the need for rapid adaptation to modern dynamic life and the conditions of practical activity. The vast array of current legislation, its frequent changes, the presence of gaps and conflicts in it require lawyers to have a high level not only of theoretical knowledge, but also of law enforcement practice. At the same time, the experience shows that the relationship between educational institutions and the field of graduates' activity is not always reliable. Young legal professionals, after defending their graduate qualification work, as a rule, do not yet know how to correlate and use in practice the knowledge they have gained during their training from various branches of law. 
The information from one branch of law in the student's mind exists separately from the information from another, while in real work everything is so interconnected that it is often difficult to determine where one branch of law ends and another begins. A young specialist needs a lot of time for the adaptation to an independent professional work. In this regard, in modern conditions, the question of finding new ways and methods of teaching that can form psychological skills and abilities in the minds of future lawyers for the practical use of constantly changing legislation becomes particularly relevant. To minimize or eliminate the time required for future lawyers to adapt to their chosen profession, they need to master the techniques and methods of an effective use of the large amount of abstract knowledge they have acquired.

As the data obtained show, from the very beginning of their professional career, most novice workers in the field of law undergo serious difficulties associated not only with the lack of professional experience, but also with insufficient psychological preparation for solving a number of communicative, emotional, cognitive problems, as well as problems associated with a high level of moral and volitional tension of legal work. These conclusions are confirmed by the results of surveys of work experience internship supervisors and people responsible for the initial professional training of novice employees in law enforcement bodies.

All of the above points to the existence of serious contradictions in the theory and practice of professional training of future lawyers. The solution of this contradiction is impossible without intentional work for improving the effectiveness of the development of the future lawyer's professional self-consciousness in two directions: the formation of knowledge and skills necessary for young lawyer professionals in the changing social and economic relations, and the development of professionally important personal characteristics that enable young lawyer specialists not only to adapt to the specifics of professional activity, but also to start the work with the greatest benefit for their personal development.

\section{PURPOSE}

Nowadays the problem of professional self-consciousness of a lawyer is not well-developed in psychology. Moreover, there is no unified approach to the establishment of the psychological structure, as well as a scientifically based system for the formation of professional self-consciousness of a future lawyer during the study in a higher education institution.

The main purposes of the research are the following: to determine the structural and content components and scientific substantiation of the dynamics of professional self-consciousness in legal education; to identify the structural components of professional self-consciousness of law students; to develop the diagnostic tools for assessing professionally significant characteristics of lawyers' self-consciousness; to conduct research aimed at identifying the level of development of professional self-consciousness of law students at the initial stage of training in a higher education institution; to develop and test a program for the development of professional self-consciousness of future lawyers in the context of using interactive teaching methods; to identify conditions and factors that ensure the development of structural components of professional selfconsciousness of future lawyers.

\section{MATERIALS AND METHODS}

Theoretically and methodologically the research was based on structural and systematic approach to the theory of personality and activity; the concept of personal development; structural and functional approach to the organization and activityof educational systems; the theory of psychological and pedagogical diagnostics; principles of applying a systematic approach in psychology and pedagogy developed by Russian science (A.A. Bodalev) [1]; the theory of professional attitude developed by Russian psychologists; the psychological theory of achieving professionalism in different activities; the theory of psychological and professional choice and psychodiagnostics (A.N. Leontiev) [6, 7]; the theory of professional orientation of personality; the theory of research of psychological aspects of lawyers' activity.

As a methodological tool for diagnosing the level of professional self-consciousness development, the authors used expert assessment; oral and written questionnaires in free and standardized forms, content analysis of activity products and certification characteristics, surveys, methods of psychodiagnostic testing of emotional, volitional, motivational, cognitive characteristics, as well as questionnaires for identification the orientation and self-esteem of personality; written survey of students (questionnaire); computer mathematical statistics.

The study included $1^{\text {st }}$ - and $4^{\text {th }}$-year students, professors and student group curators of the Law Faculty of the Mari State University (Russia), as well as work experience internship supervisors from the institution where it was held.

The results of the study were presented in a number of publications of the authors' team $[3,4]$. 


\section{RESULTS AND DISCUSSION}

The lack of psychological and teaching works on developing skills of future lawyers at the stage of their professional becoming prevents from using the potential resources of the personality. The use of these resources offers the broad prospects for the preparation of the creative individualities; personalities being aware of their capabilities and abilities not only to reasonably assess individual qualities but also to make the most use of them. Professional training should embrace all the stages of learning of a future lawyer: preuniversity training and education, training and education at the university and the endeavor to constantly improve the own competencies in the process of individual professional work.

The high professional level of lawyers is determined by the development of the professional selfconsciousness and can be the result of purposeful organization of the system forming future lawyers' selfconsciousness, realized during the entire university training.

The activity of lawyers, scientific, operational investigative and prosecution employees, attorneys, judges and notaries is characterized by the legal regulation (normalization) of the professional behaviour, the authoritative, binding effect of the professional powers, to a great extent the extreme type of activity, nonstandard, creative nature of work, procedural independence and personal responsibility.

Successful development of the individual's professionalism and the activity of the future lawyers should based on their high level of the professional self-consciousness that ought to be understood as a mix of functional, operational and personal elements which have a dynamic structure with functional relations [2, 5, 9].

According to the literature sources and our observations, there is currently a contradiction between the requirements for the professionally important qualities of young lawyers and their insufficient development in the process of their getting higher education. Such situation is explained by the fact that most of the educational institutions use information, or procreational learning model, aimed at students accepting information, processing it, and showing the degree of digestion. The use of such a model leads to "the loss of connection with students' actions and their needs, the content of education also loses the personal meaning... This separation from practice turns learning into rational work with concepts which begins to be interpreted as work with the theoretical knowledge. However, this is pseudo-theoretical knowledge as the theory always results from practice and is aimed at solving the practical problems with the use of theoretical knowledge and theoretical method" [8].

Besides, according to the analysis of the lawyers' new qualification profiles, this model of learning purposefully forms, first of all, minimum essential knowledge, to a lesser extent the professional skills and it is poorly aimed at the development of students' professional self-consciousness which allows specialists to perform their duties effectively.

At the same time, the analysis of the system of requirements for the specialists in the field of law and lawyers performance qualifications for different profiles show that the legal professions are characterized by the following competencies: high level of social (professional) adaptation (high level of legal consciousness, honesty, adherence to principle, commitment, discipline, duty performance), neuropsychic (emotional) stability of moral and emotional-volitional qualities of the personality (high level of self-control, stress resistance, developed adaptive properties of nervous system, independence, administrative ability, selfstarter, sense of responsibility for the actions), high level of intellectual development, mental (cognitive) activity (developed intelligence, creative thinking, analytical mind-set, ability to identify the essentials, developed imagination, intuition), communicative competence (the ability to establish contacts with the communicators, insight, listening skills, kindness).

The professional self-consciousness of a lawyer as an integral characteristic of an individual has its own specific psychological structure, the main components of which are:

- The motivational component, which shows itself in an interest in the work process and its results; the attitude towards studying special subjects and literature, a desire for professional growth;

- The cognitive component, which shows itself in the special properties of thinking - the ability to establish cause-effect relations; heuristicity as the independence and distinction in finding ways and techniques to obtain the necessary information; reflexivity as the ability to anticipate the likely actions of procedural opponents;

- The affective volitional component, which shows itself in a high level of volitional regulation and resistance to the use of tactical tricks by procedural opponents, as well as in tolerance to possible threats, aggressive 
actions by those involved in the case and to the negative impact of external disturbances (noise, presence of unauthorised persons);

- The communicative component, which is found in the ability to establish psychological contact with people involved in a case; in the ability to resolve conflict situations arising in the course of professional activity, in fluency of verbal and non-verbal techniques and methods of professional communication.

The effectiveness of the professional lawyers' activity is largely ensured by the dynamic development of professional self-consciousness, which is an activity and personal characteristic of the subject of work reflecting the level of its development and potential capabilities.

A factor in the formation of lawyer's professional self-consciousness is the use of interactive teaching methods in the educational process which include psychological trainings, modelling of professional activity in the educational one, problem-based teaching, the method of fundamentalization, Socratic dialogue, video presentations, business and role-playing games, etc. Such methods create the real atmosphere of business cooperation in solving possible professional problems and are optimal for forming the future lawyer's professional self-consciousness.

Подобные технологии обучения способствуют превращению студента из объекта педагогического воздействия В активный субъект научно-познавательной и практически-производственной деятельности.

Interactive teaching methods are aimed not only at the development of individual cognitive processes, abilities, skills of a student, but also at the development of professional self-consciousness of a future specialist, namely, the development of sustainable cognitive and social motives, interests, aspirations for the effective acquisition of knowledge and methods of future professional activity, the development of communicative qualities, mobilization of volitional efforts aimed at solving the tasks set. The use of interactive methods in training future lawyers is the most pedagogically effective, as they create conditions for students' self-development in creative learning activities, help to adapt to the specifics of future work as a lawyer. Such learning technologies help to transform the student from an object of pedagogical influence into an active subject of scientific and educational, as well as practical and operational activity.

\section{CONCLUSION}

Based on the results of the theoretical and experimental research and the actual practice of using interactive teaching methods at the Faculty of Law, the authors have made the following conclusions.

1. Based on the theoretical basis of well-known domestic and foreign researchers, we can talk about professional self-consciousness as a special phenomenon of the human psyche, which determines the personality's self-regulation of their actions in the professional sphere on the basis of knowledge of professional requirements, professional capabilities and emotional attitude towards themselves as a subject of professional activity.

2. The excellence of the professional self-consciousness of a future lawyer at the stage of university training is one of the conditions for the successful implementation of professional duties in the conditions of real labour activity.

Professional self-consciousness of a lawyer is an integrative and personal education with such components as communicative, cognitive, affective volitional and motivational ones.

3. The phenomenon of professional self-consciousness has not been fully studied for today. The real task of modern researchers in the scientific fields of labour and educational psychology is to see and understand the ways for its formation and development and to determine the mechanisms for filling self-consciousness with competence components.

4. A comparative analysis of the psychological testing results of law students at the initial and final stages of training showed that in the process of professional development of lawyers in a higher educational institution in the context of using traditional information technologies, the professional self-consciousness of students does not fully develop.

5. The results of the educational experiment indicate that the level of development of the main structural components of students' professional self-consciousness becomes higher as a result of using the interactive teaching methods, such as trainings, role-playing games, Socratic dialogue, problem-based seminars, video presentations and other types of training exercises that ramp up students' educational activities.

6. Teaching technologies based on cooperation of students and teachers, when both become the subjects 
of learning, are optimal for the development of professional self-consciousness. In the conditions of such an educational process, all participants interact with each other, evaluate their own actions and the actions of their coursemates; students are immersed in a real atmosphere of business cooperation, which, in general, is optimal for developing the professional qualities of a future lawyer.

7. The interactive methods of teaching students imply a detailed development and inclusion in the educational process of special courses and special practical classes: the culture of a lawyer's speech; introduction to the profession, professional ethics and standards of anti-corruption behavior; legal advice; preparation of criminal and civil procedural documents; lawyer in criminal proceedings; legal expertise of regulatory legal acts; forensic investigation of the scene; digital technologies in legal activity; legal conflictology; judicial debate.

\section{REFERENCE LIST}

1. Bodalev, A.A. Psychology of communication. - Moscow: MSU Publishing house. UN-TA, 1996. - 256 p.

2. Bodrov, V.A. The psychology of professional suitability. - Moscow: PER SE, 2001. - 511 p.

3. Demidov M., Smirnov M., Starygina P., Yakhina O. DEVELOPMENT OF PSYCHOLOGICAL STRUCTURE PROFESSIONAL LAWYER'S SELF-CONSCIOUSNESS IN THE CONDITIONS OF HIGHER EDUCATION // Proceedings of SOCIOINT 2020- 7th International Conference on Education and Education of Social Sciences, 15-17 June 2020. - P. 294-299.

4. Demidov M., Smirnov M., Starygina P., Yakhina O. THE USAGE OF INTERACTIVE TRAINING METHODS IN THE DEVELOPMENT OF FUTURE LAWYER'S PROFESSIONAL SELFCONSCIOUSNESS // Proceedings of SOCIOINT 2020- 7th International Conference on Education and Education of Social Sciences, 15-17 June 2020. - P. 300-304.

5. Derkach, A.A., Orban, L.E. Aacmeological essentials for professional becoming. - Moscow: RAGS, 1995. -208 p.

6. Leontiev, A. N. Activity. Consciousness. Personality. - Moscow: Politizdat, 1972.

7. Leontiev, A. N. Activity. Consciousness. Personality. - Moscow: Politizdat, 1975.

8. Shadrikov, V.D. Anthological concept of education (the neolithic paradox) // The anthology of modern psychology at the end of the XX century / Ed.-in-chief. R.V. Gabreev. - Kazan, 2001. - P. 233-243.

9. Shadrikov, V.D. Activity and abilities. - Moscow: Logos, 1994. - 320 p. 